\title{
El discurso godardiano en vivre sa vie (1962)
}

Santiago Andrés Segura Berrío*

DOI: https://doi.org/10.33571/revistaluciernaga.v12n23a7

\section{Resumen}

Se presenta la reflexión producto de investigación del análisis del film Vivre sa vie (Godard, 1962) el cual se basó en la propuesta de Jacques Aumont y Michell Marie (1990), en las teorías de Bordwell, Burch y Bergala así como en entrevistas a expertos de cinematografía en la ciudad de Medellín.

La manera de vivir el cine implica la idea canónica del entretenimiento, para Godard, también involucra la capacidad de construir metáforas e ideas para un espectador reflexivo. Éste director propone un modelo desafiante y transgresor con un discurso collage, que se constituye en desafío mental para el público. En Vivre sa vie, presenta modelos "nuevos" de cinematografía tales como el teatro épico y la narrativa paramétrica, los cuales aportan argumentos renovadores al cine.

Palabras clave: Vivre sa vie; lenguaje cinematográfico; Jean-Luc Godard; teatro épico; narrativa paramétrica; canon fílmico hegemónico hollywoodense; narrativa, estética.
Recibido. Febrero 3, 2020
Aceptado. Febrero 18, 2020

\footnotetext{
* Comunicador y Periodista de la Corporación Universitaria Lasallista. En desarrollo de su plan de estudios orientó sus preferencias formativas hacia el campo de la cinematografía. Su trabajo de grado para optar al título lo realizó con el proyecto de investigación "Transgresiones del canon fílmico hollywoodense en Vivre sa vie (1962) de Jean-Luc Godard", el cual fue presentado en el evento institucional Muestra Audiovisual de 2017. Orcid: https://orcid.org/0000-0002-3990-6876 ; e-mail: sasegura@ulasallista.edu.co
}

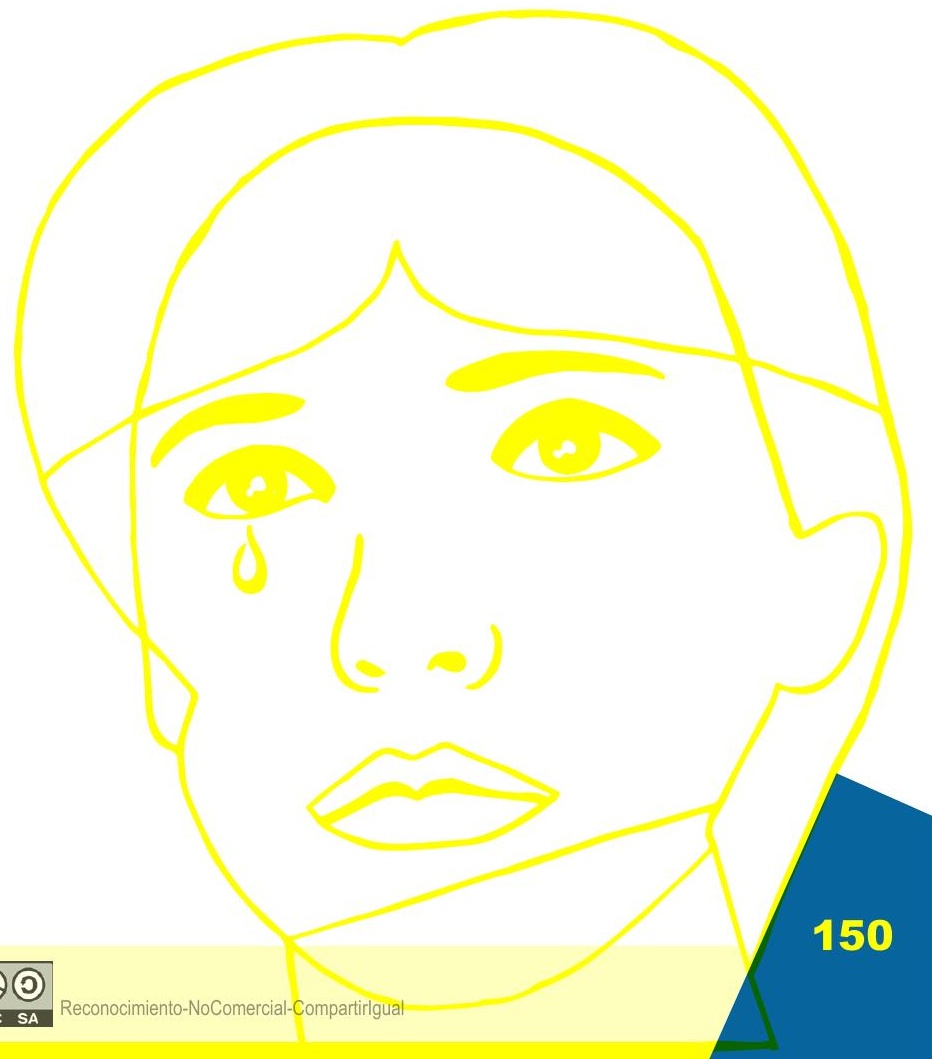




\title{
The godardian discourse in vivre sa vie (1962)
}

\author{
Santiago Andrés Segura Berrío*
}

DOI: https://doi.org/10.33571/revistaluciernaga.v12n23a7

\section{Absrtact}

It is presented the reflection resulting from the analysis of the film Vivre sa vie (Godard, 1962) which was based on the proposal of Jacques Aumont and Michell Marie (1990), on the theories of Bordwell, Burch and Bergala as well as on interviews with film experts in the city of Medellin.

The way of experiencing movies implies the canonical idea of entertainment, for Godard, it also involves the ability to build metaphors and ideas for a reflective viewer. This director proposes a challenging and transgressive model with a collage discourse, which constitutes a mental challenge for the audience. In Vivre sa vie, it is presented "new" models of cinematography such as epic theater and parametric narrative, which introduce renovating arguments to cinema.

Keywords: Vivre sa vie; cinematographic language; Jean-Luc Godard; epic theater; parametric narrative; Hollywood hegemonic film canon; narrative, aesthetics

Received. February 3, 2020

Accepted. February 18, 2020

"Communicator and Journalist of Corporación Universitaria Lasallista. His research, "Transgressions of the Hollywood film canon in Jean-Luc Godard's Vivre sa vie (1962)," was shown at the institutional event Muestra Audiovisual of 2017. Orcid: https://orcid.org/0000-0002-3990-6876 : e-mail: sasegura@ulasallista.edu.co 


\section{O DISCURSO GODARDIANO EM VIVRE SA VIE (1962)}

Santiago Andrés Segura Berrío*

DOI: https://doi.org/:10.33571/revistaluciernaga.v12n23a7

\section{Resumo}

A reflexão é apresentada como resultado da análise do filme Vivre sa vie (Godard, 1962) que foi baseado na proposta de Jacques Aumont e Michell Marie (1990), nas teorias de Bordwell, Burch e Bergala, bem como em entrevistas com especialistas em cinema na cidade de Medellín.

A forma de viver o cinema implica a idéia canônica de entretenimento, para Godard, envolve também a capacidade de construir metáforas e idéias para um espectador reflexivo. Este diretor propõe um modelo desafiador e transgressivo com um discurso de colagem, o que constitui um desafio mental para o público. Em Vivre sa vie, ele apresenta "novos" modelos de cinematografia como o teatro épico e a narrativa paramétrica, que trazem novos argumentos renovadores para o cinema.

Palavras chave: Vivre sa vie; linguagem cinematográfica; Jean-Luc Godard; teatro épico; narrativa paramétrica; cânone cinematográfico hegemônico de Hollywood; narrativa, estética.

\section{Recebido Fevereiro 03,202}

Aceitado. Fevereiro18,2020

\footnotetext{
* Comunicador e Jornalista da Corporação Universitária Lasalliana. Sua pesquisa, "Transgressões do cânone do filme de Hollywood em Vivre sa vie (1962) de Jean-Luc Godard", foi apresentada no evento institucional Show Audiovisual de 2017. Orcid: https://orcid.org/0000-0002-3990-6876 ; e-mail: sasegura@ulasallista.edu.co
}

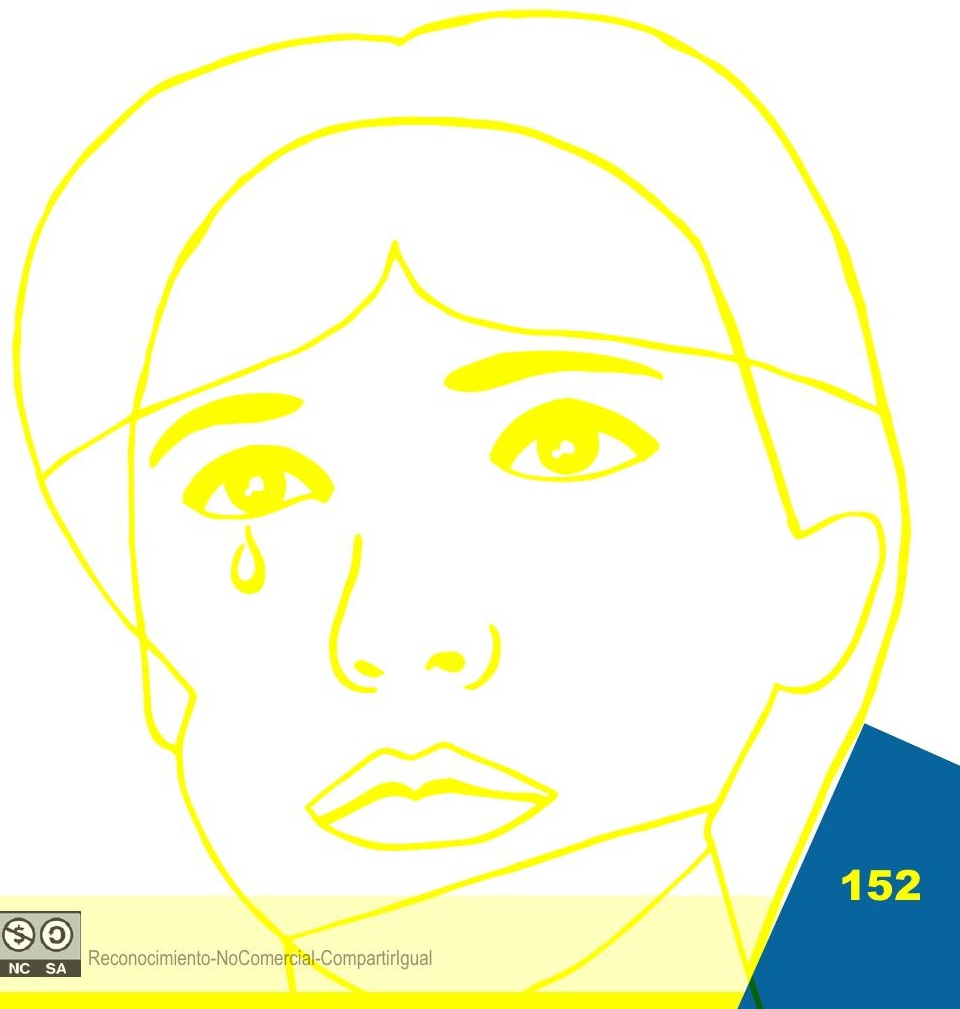




\section{Introducción}

Jean-Luc Godard, fue un crítico y director de cine francosuizo, entre sus películas más conocidas están: À bout de souffle, (1960) o Le mépris, (1963). Godard, comenzó a escribir su nombre en la historia del cine en la revista Cahiers du cinema [1], allí surge el movimiento la Nouvelle Vague (Baecque, 2004). A Godard se le conoce como transgresor y renovador.

Decidió implementar nuevas formas de expresar relatos y emplear la estética, explorando el cine a modo de cine: un sistema de encadenar imágenes y sonido para consolidar un argumento (Bordwell, 1985).

En general se le definió como L'enfant terrible [2], esto es un hombre incómodo que destruye, crea y transforma a lo largo de su obra. Entre las temáticas abordadas por este director están: el amor, la comunicación, el lenguaje, las guerras y las relaciones mercantiles de la sociedad actual. Algunos cineastas han sido influenciados por su obra, como por ejemplo los colombianos Óscar Campo, Jorge Echeverry y Luis Ospina.

Los principios que rigen el lenguaje de la cinematografía godardiana buscan expresar ideas por medio de metáforas visuales y sonoras. Godard desea transmutar, variar, renovar y refrescar los relatos, en otras palabras: denota la construcción de un collage (teatro épico, narrativa paramétrica) para consolidar un discurso connotativo en la audiencia. Su principio, y del cual se desprende todo el pensamiento godardiano, es el de plantear posibilidades de representar y plasmar las diferentes facetas de la existencia humana con las imágenes y el sonido: no limita los recursos, los expande y yuxtapone sin crear convencionalismos; amplia los paradigmas en la narración y la estética.

"Godard, en otras palabras, plantea la posibilidad, como ningún otro director lo ha hecho, de un uso de la técnica puramente caprichosa o arbitraria” (Bordwell, 1985, pág. 312).

El segundo principio de Godard: es que el film debe ser comprensible. El espectador tiene la tarea de comprender las metáforas desde su cognición biográfica; debe interpreta, descifra y crea la historia fraccionada que se le ha expuesto. Este proceso se puede observar en la llustración 1, cuya lectura debe hacerse de izquierda a derecha.

\section{llustración 1. Proceso de los principios godardianos}

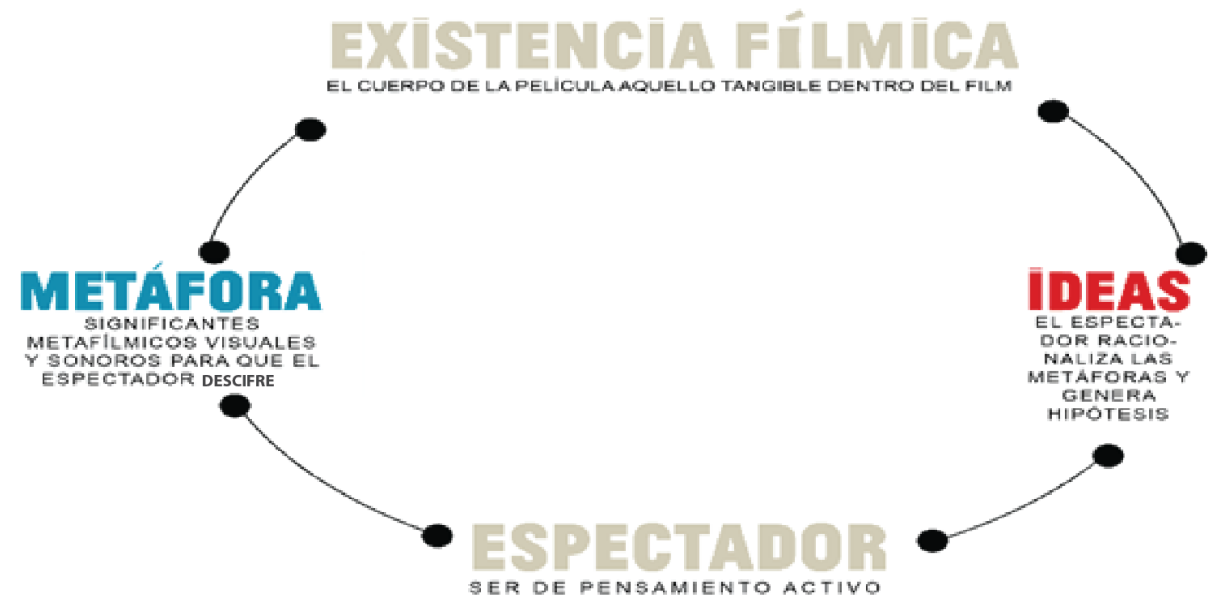

Fuente: elaboración propia a partir de La narración en el cine de ficción de Bordwell (1985) 
La existencia fílmica, se refiere a la película misma la cual tiene un contenido; un cuerpo que propone unos elementos perceptibles. Lo metafórico, hace referencia a la construcción de significantes [3]. El espectador, es quien debe leer la película, sus significantes, pasar de sujeto-pasivo a sujeto-activo. Éste racionaliza [4] los significantes, les brinda significados [5] (ideas). Cuando el espectador no construye significados sobre el significante, genera hipótesis y trata de racionalizar hasta alcanzar alguna idea sobre la metáfora. Si el espectador no ha conseguido construir un significado sobre el significante, seguirá generando hipótesis y racionalizando hasta alcanzar una idea sobre la metáfora.

\section{Vivre sa vie}

Vivre sa vie, es un film en el que se describe la vida de una mujer dócil e idealista, muy frágil, la cual quería ser actriz de cine pero termina en una tienda de discos. Es una cinta que muestra qué ocurrió, pero no por qué ocurrió. Rechaza la causalidad [6]. Muestra lo que es y lo que existe: el presente, lo que ocurre, el "yo" que es transmutado por el contexto. Sin saber por qué, pero se podría intuirse que lo hace por problemas económicos. Ella acaba como prostituta de una red mafiosa, se enamora, y es asesinada en una lucha entre dos mafias (Bordwell, 1985).

Vivre sa vie, es un film que, como comenta Bordwell, habla de "una radiografía del panorama de la prostitución parisina" y sobre la dificultad de la comunicación (Bordwell, 1985, pág. 282).

Imagen 1. Nana en su contexto, intentando sobrevivir trabajando en la prostitución pues sus sueños se ven frustrados.

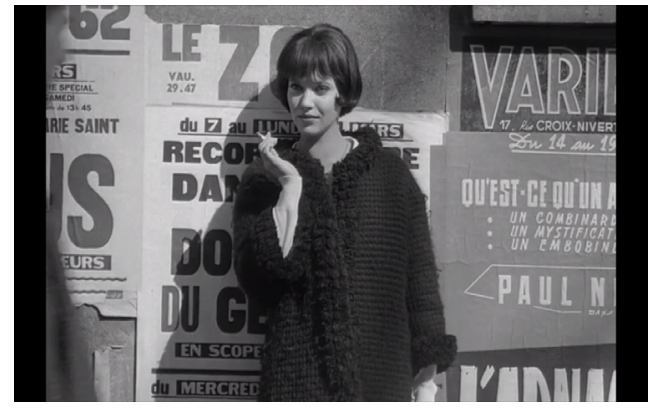

Imagen 2. Nana demuestra la problemática de comunicación, pues es indiferente ante su cliente en el encuentro sexual.

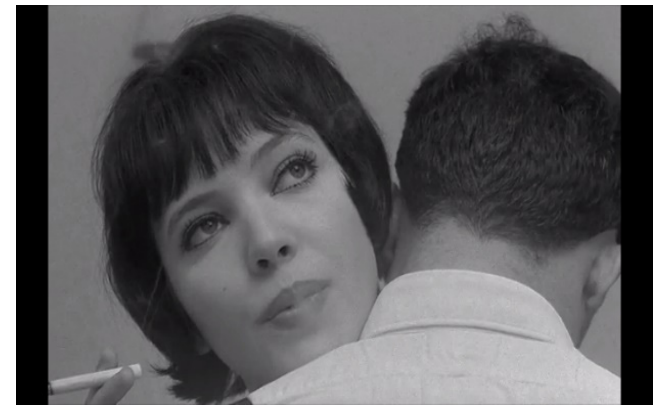

En el film yace una realidad fraccionada, narrada en doce tableaux [7], relata la historia de un sujeto fragmentado, que atraviesa por la sociedad francesa decadente de la postguerra. Contiene elementos narrativos y estéticos que renovaron el cine en los años 60. Vivre sa vie (Godard, 1962), es un film renovador y refrescante que la convierten en una obra que plantea nuevos componentes.

A continuación, procedemos a desglosar, una por una, las características que subyacen dentro del argumento y dentro de la estilística de Vivre sa vie.

\subsection{El teatro épico en Vivre sa vie}

Para Arias (2017), en el modelo narrativo de Vivre sa vie, se encuentra la fusión de relatos y de formas argumentales, es decir el collage de Godard al narrar. La forma narratológica del film es, como argumenta Javier Villar Bibián: la estructura teatral épica o brechtiana (Bibian, 2006), la cual busca una relación de empatía con el espectador a través de la interacción entre la puesta en escena y el público, donde se genera un espacio de racionalización del contenido de la obra, o lo que es lo mismo, conciben al sujeto sentado en su butaca como un ser pensante, capaz de generar un discurso frente a lo que acontece en la cámara oscura (Pineda, 2018). 


\section{llustración 2.}

\section{Collage del discurso godardiano, el teatro épico y la narrativa paramétrica}

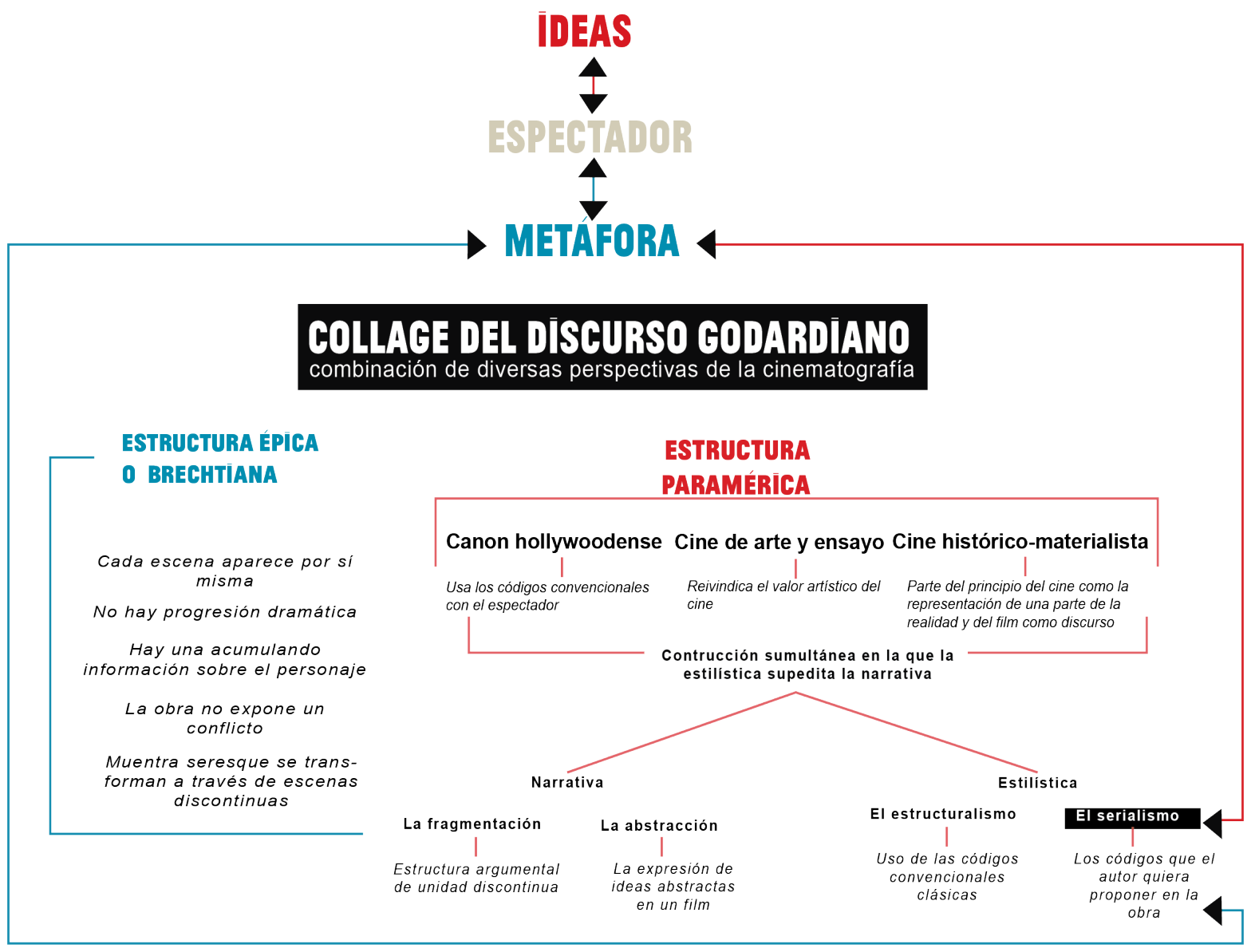

Fuente: elaboración propia a partir de toda la bibliografía consultada.

Hallamos una trama desarrollada de manera fragmentada en la que hay una disposición dividida de las ideas y metáforas que nos narran unas transformaciones en la vida de Nana: sus rupturas amorosas, sus trabajos, su vida, su muerte. Ante estas variaciones en su ambiente cotidiano ella se ve obligada a transmutar. La película no narra un conflicto, relata unos sujetos pasajeros que se (re) envuelven en unas situaciones predeterminadas por las condiciones sociales de la época. El film ofrece una representación de la realidad desde distintas perspectivas en la condición del presente de Nana, en las que se entiende que vive dentro de un contexto que no le favorece.

Al profundizar en el film se encuentra características en su estructura que hacen pensar en las épicas o brechtiana [8]: 
- "Cada escena aparece por sí misma. No hay progresión dramática, sino que se van acumulando informaciones sobre el personaje y el mundo en el que vive" (Bibian, 2006, pág. 104).

- Dilucidamos una película fraccionada que narra lo acontecido en doce tableaux, sin necesidad de un desarrollo cronológico clásico, narradas de manera independiente. Tableaux en los que Nana tiene su propio universo, donde se generan momentos con un ritmo ligero, y ella transita por todos estos universos sin necesidad de una relación de causa y efecto que tenga que presenciar el espectador.

- "La obra no expone un conflicto, sino que narra una historia mostrando a seres y cosas en transformación a través de escenas discontinuas" (Bibian, 2006, pág. 104).

\subsection{La estructura paramétrica en Vivre sa vie:}

La construcción estilística y narrativa de Vivre sa , deviene de la narrativa paramétrica [9], según Burch estos son los elementos que hacen parte de la composición de la obra fílmica. Al respecto señala:

"El filme se hace ante todo de imágenes y sonidos; las ideas [10] intervienen más tarde. Existe una relación dialéctica entre los parámetros del film, una contradicción en la disposición compuesta, donde cada parámetro lo considera una alternativa narrativa que desea comunicar algo más allá de lo específico. (Burch, 1979, pág. 150).

En otras palabras, la estilística genera el argumento. Hay independencia de la estilística hacia la narrativa, donde la primera no debe estar supeditada a la segunda, caso contrario al de Hollywood [11]. Es una estructura que resalta la construcción simultánea de todos los elementos de la obra, dentro de cada encuadre: la fotografía, la composición, el color, el decorado, la iluminación, el sonido, la música y el montaje llegan a tener significantes yuxtapuestos unos con otros, que no reflejan una unidad, pero que cada uno intenta formular una relación de "código semiótico" [12] que confiere una interrelación de ellos y constituye un argumento.

Esta estructura es considerada como un collage en sí misma, pues recoge elementos del canon hollywoodense [13], del cine de arte y ensayo [14] y del cine histórico-materialista soviético [15]. Por tanto, este concibe dos elementos fundamentales en cuanto a lo narrativo, los cuales trata Bordwell (1985).

- La fragmentación, la cual termina consolidando el modelo de estructura argumental y estilística como una unidad discontinua.

Se refiere a los tableaux del film que son divididos por intertítulos. Segmentaciones en las que Godard decidió presentar al espectador su film, donde se van forjando en cada uno intra-narrativas que representan diversas facetas de la vida de Nana: sus sentimientos, su relación con los hombres, el trabajo, su vida. Es un relato que no conduce a un final. Una mezcla de fragmentos accidentales que no suceden por el orden causal, donde el espectador es partícipe de ese misterio, va guiando y complementando la lectura del film.

- La abstracción (Bordwell, 1985), la expresión de ideas abstractas en un film.

Se puede indicar que Vivre sa vie, presenta diferentes abstracciones - las metáforas que expresan el lenguaje cinematográfico puede abordar construcciones argumentales como medio de representación de ideas abstractas y complejas de expresar-. Esto se aprecia a través del símil 
entre Nana y Juana de Arco; Godard muestra la identificación entre ambas al hacer uso del cine dentro del cine (ver imágenes 3 y 4). Presenta el personaje, y nos narra su condena social por su condición de mujer en una estructura de intercambio mercantil de los cuerpos.

Imagen 3. Nana ve La Passion de Jeanne Imagen 4. Nana reacciona a La Passion de 'Arc en el cinéma. Jeanne d'Arc en el cinéma.
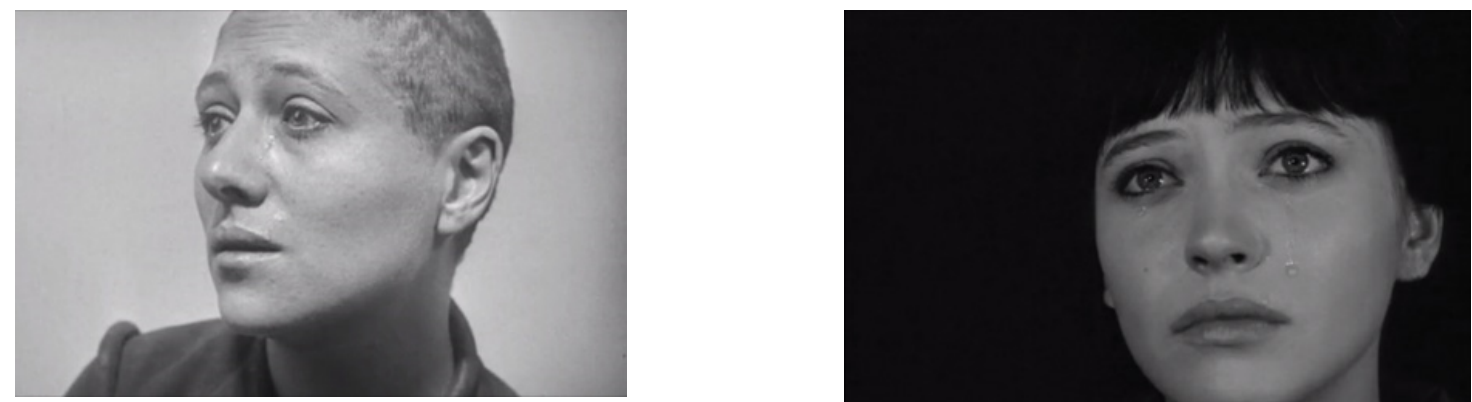

Además de las características que nos propone Bordwell para entender el componente narrativo, también nos ofrece un par de categorías para la parte estilística.

- El estructuralismo [16], se refiere al uso de las estructuras convencionales o clásicas: el uso del canon filmico hollywoodense.

En el estructuralismo, la composición estética de la obra o el manejo del lenguaje cinematográfico, se basa en una estructura clásica o hollywoodense, para que la obra sea comprensible y haya un código común. Lo podemos ver en las imágenes 5 y 6 , en las que hay uso del campo contra campo [17] clásico, evidenciando el elemento estructuralista.

Imagen 5. Nana indagada por la policía Imagen 6. El policía interroga a Nana en campo contra campo canónico. en campo contra campo.
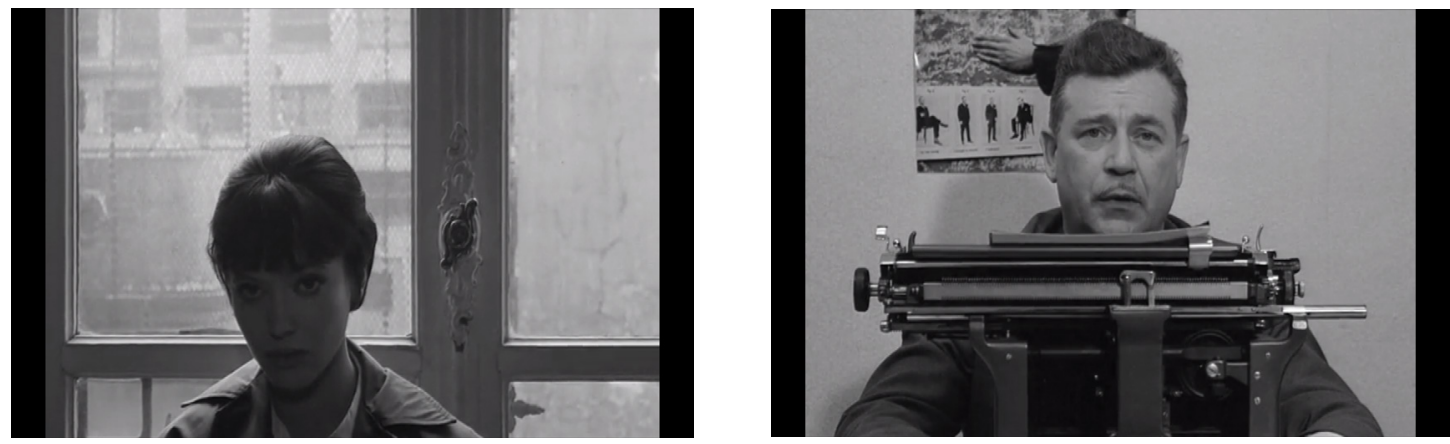

Ante la propuesta del estructuralismo, surge en cadena como reacción a éste: el serialismo, del cual se desprenden los códigos que el autor quiera proponer en la obra.

En Vivre sa vie (ver imagen 7) se observa cuando Raoul le ofrece a Nana trabajar con él. Pero también se encuentran significantes en los elementos del encuadre. 


\section{Imagen 7.}

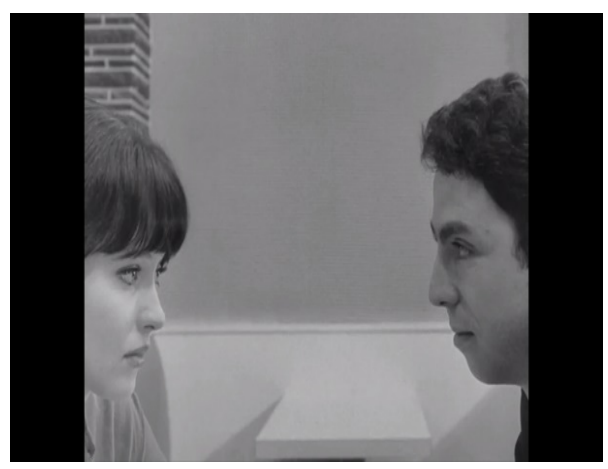

Primero, Nana durante el film, expresa la necesidad de comunicarse sin tener que hablar y entre más se habla, más se está mintiendo. Segundo, en la imagen apreciamos esta metáfora visual, a esta idea que es expresada recurrentemente en lenguaje articulado. ¿Cuál es la metáfora? Al ver el encuadre, se recuerda a la idea de la "estructura de la comunicación": emisor, mensaje y receptor. Nana en ese plano con ese gesto de "hablar sin hablar" con Raoul, queda convencida de él y accede a ser su prostituta, atada a su idea de la necesidad de comunicarse sin palabras; y le creyó a Raoul, porque justamente no le dijo nada en ese momento.

Se puede observar en la Tabla N1, el desarrollo de éste como un ciclo continuo entre el film y el espectador en el que se espera se generen metáforas que permitan racionalizar ideas. La propuesta es "pensar entre imágenes". Deviene entonces una ineludible necesidad de ejemplificar cada uno de los elementos serialistas del film.

Tabla 1.

Análisis de los elementos serialistas del film

\begin{tabular}{|c|c|c|c|c|}
\hline 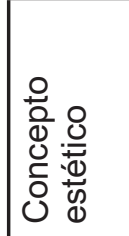 & Imagen a analizar & Su uso en el film & Descripción de la imagen & $\begin{array}{l}\text { Objetivo del } \\
\text { elemento } \\
\text { estético }\end{array}$ \\
\hline 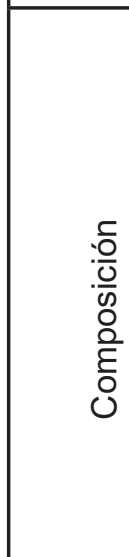 & & $\begin{array}{l}\text { La disposición de Nana } \\
\text { en el espacio fílmico } \\
\text { corre a cargo de un orden } \\
\text { predeterminado. Su lugar } \\
\text { en el cuadro y aquello } \\
\text { que la rodea está previsto } \\
\text { conforme a una necesidad } \\
\text { de narrar la sensación de } \\
\text { insatisfacción de Nana } \\
\text { con su entorno. }\end{array}$ & $\begin{array}{l}\text { Ubicamos a Nana en el } \\
\text { borde inferior del plano, } \\
\text { dándole la espalda a } \\
\text { la relación sexual que } \\
\text { acontece tras de sí, } \\
\text { evidencia la función } \\
\text { semiótica que Godard nos } \\
\text { quiere expresar de Nana } \\
\text { en este momento del film: } \\
\text { la soledad y la sensación } \\
\text { de no pertenencia al } \\
\text { lugar que la rodea, en un } \\
\text { momento en el que se } \\
\text { pregunta si es feliz o no }\end{array}$ & $\begin{array}{l}\text { Reflejar las } \\
\text { emociones y su } \\
\text { relación con el } \\
\text { contexto y las } \\
\text { situaciones que } \\
\text { le acontecen. }\end{array}$ \\
\hline
\end{tabular}




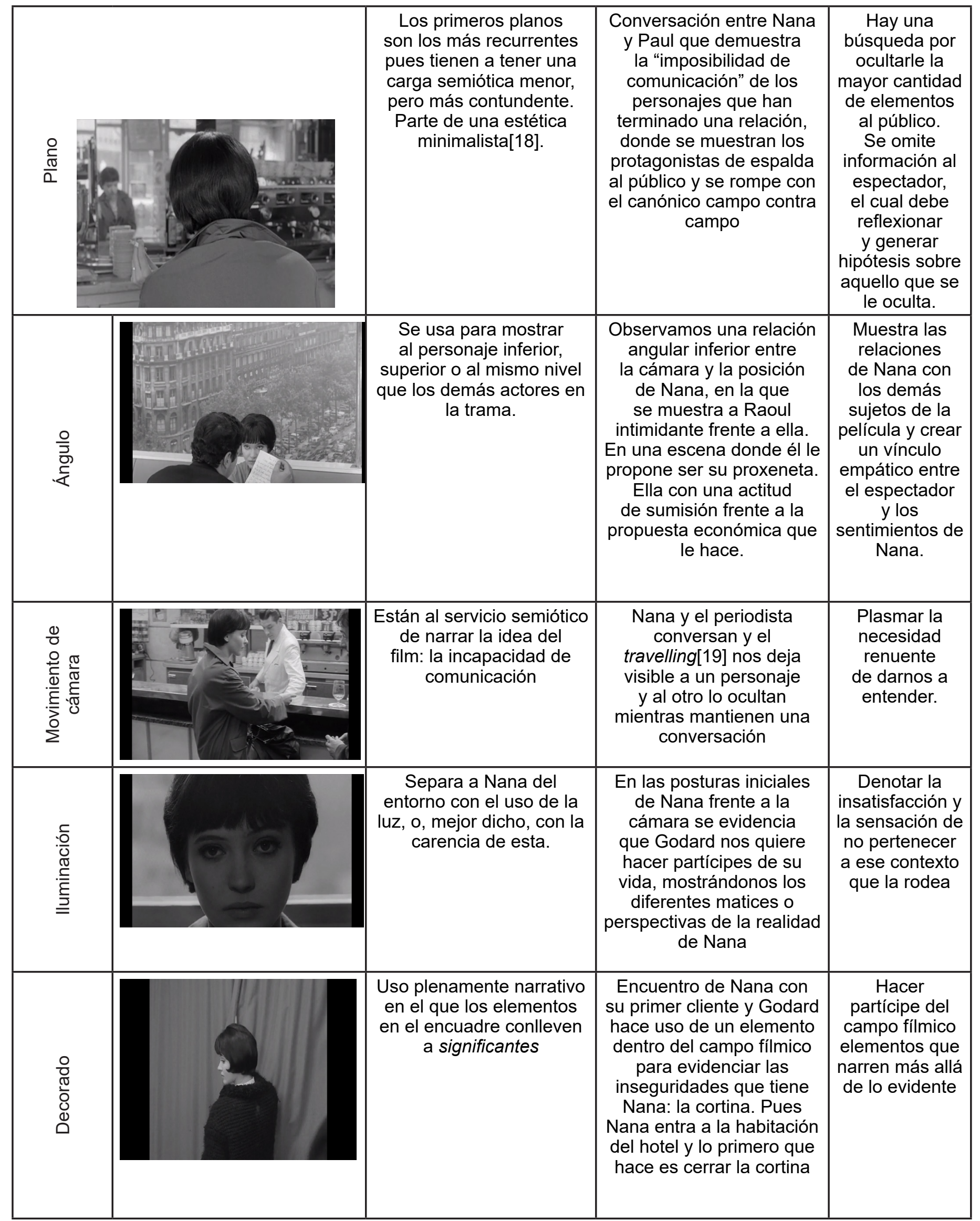




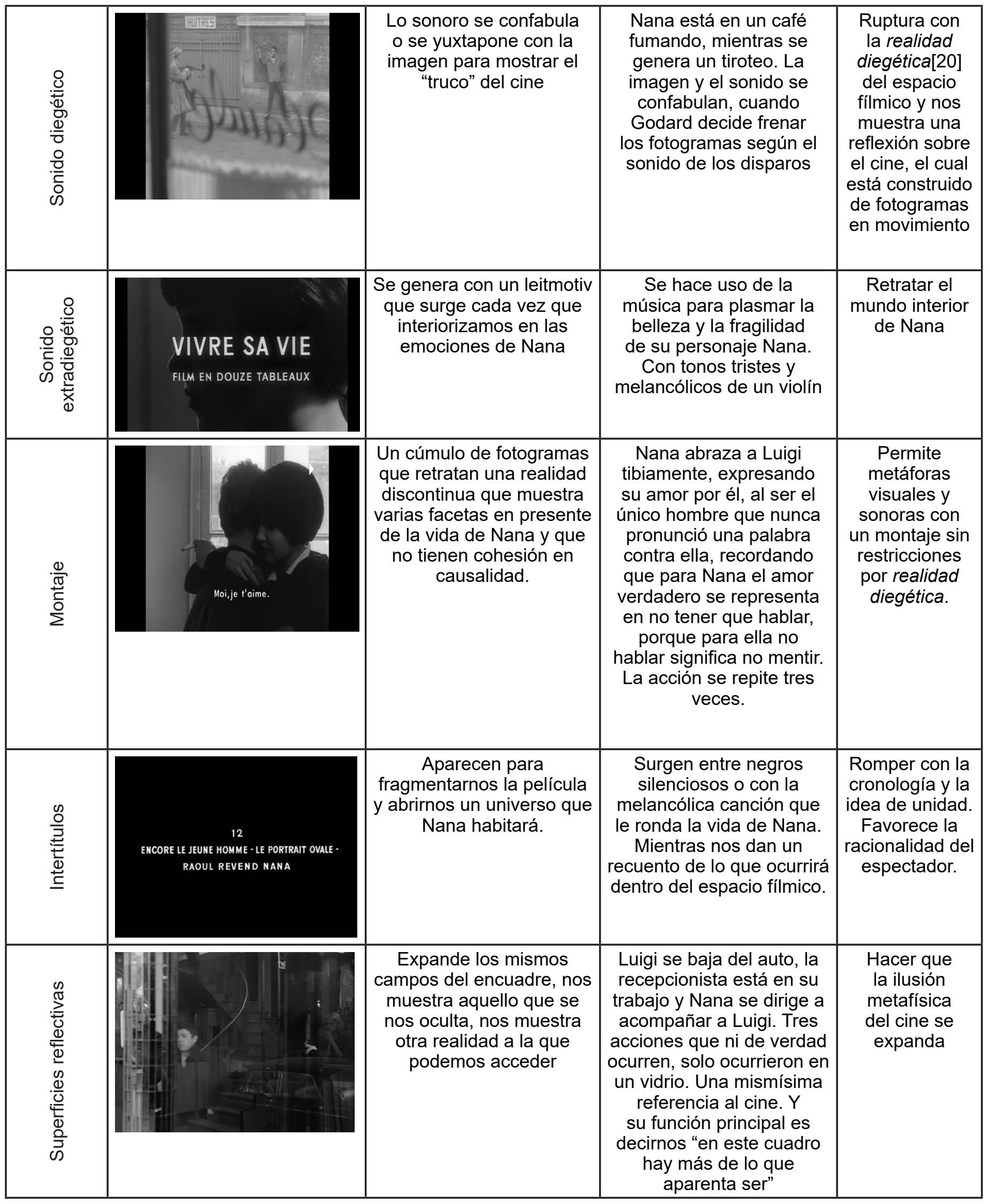




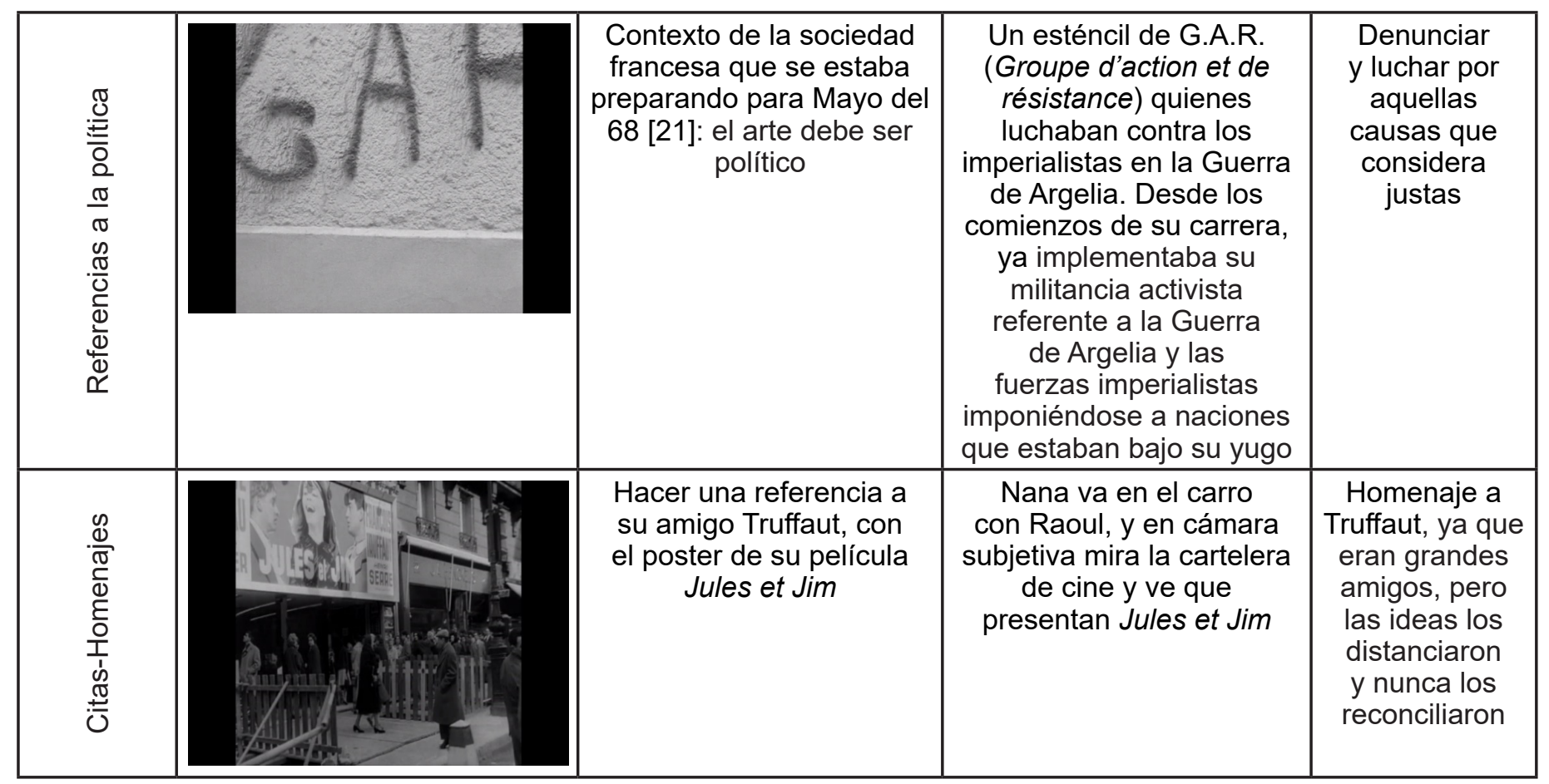

Fuente: Elaboración de autor a partir de la bibliografía consultada.

\section{Conclusiones}

Godard que conocía a la perfección el funcionamiento la construcción narrativa y estética del canon fílmico hegemónico hollywoodense, que se basa en es un sistema de convenciones o códigos comunes entre el espectador y el film, plantea otras lecturas desde éste, construidas a partir del teatro épico y con la estructura paramétrica.

Cuando la normativa impone un modelo hegemónico que dictamina que el cine es el medio para contar el argumento; debe haber un atrevimiento racional que confronte ese pensamiento, para desde allí, llegar a argüir que, en realidad, el cine es el fin mismo del argumento. Aquí aparece la transgresión. Vivre sa vie, construye con este "truck", el teatro épico y la narrativa paramétrica, pero con un aire fresco y renovador del cine. En tal sentido la importancia de Jean-Luc Godard como un transgresor que modernizó las narrativas y las historia. Él comenzó a pensar diferente: ambicionó pensar como un enfant terrible.

Como lo señala la literatura, aunque los modelos del vivir el cine contienen la idea canónica del entretenimiento, Godard, y muchos otros personajes, sabían que éste tiene capacidad para más. Como señala Piaget (2009) Godard observó que ¡el cine es más que entretenimiento!, y decidió usarlo como medio discursivo para expresar metáforas y construir ideas. Comprendió que el cine no sólo estaba para entretener y que había espectadores que tampoco estaba para seguir en esa ingesta. Entendió que los espectadores pueden pensar, a través de estímulos y reaccionar ante estos. Así, con este modelo desafiante y transgresor, percibió que a través de su collage: estructura del teatro épico, estructura paramétrica: clasicismo hollywoodense, cine arte y ensayo y el cine histórico-materialista; la paramétrica narrativa: fragmentación y abstracción; paramétrica estilística: estructuralismo y serialismo, representaba un desafío para la construcción mental del público. También podría hacer eso que quería: expresar metáforas y construir ideas para un espectador reflexivo. 
Si desde la producción cinematográfica se sigue tratando al espectador como un ser digestivo, de pensamiento pasivo, como lo hace Hollywood, se continuará promoviendo modelos de pensamiento limitados, alienadores discursivamente hablando. Es hora de comenzar a ampliar los saberes, a transcender paradigmas, a ser democráticos con los conocimientos, a no marginar ideas por el "utilitarismo". Se comprende -lo cual no significa que sea aceptable- que se busque un cine pensado desde lo mercantil. Es el momento de darle a este nuevo tipo de construcciones narrativas y estilísticas un lugar en la formación de los nuevos cineastas. Es necesario y pertinente, producir contenidos que hagan pensar a la sociedad, que se motive el pensamiento activo; de allí que incluir a Godard, y su obra en el aula podría ser un pretexto para alentar el cuestionamiento, el debate, la generación de hipótesis y en sí la construcción de nuevas miradas.

\section{Referencias}

Arias, M. F. (7 de Diciembre de 2017). Canon fílmico hegemónico hollywoodense. (S. A. Berrío, Entrevistador)

Aumont, J., Bergala, A., Michel, M., \& Vernet, M. (2008). Estética del cine. Buenos Aires: Paidos comunicación.

Baecque, A. D. (2004). Una cinefilia a contracorriente: La Nouvelle Vague Y El Gusto Por el cine Americano. Barcelona: Paidós Colección.

Bibian, D. J. (26 de Junio de 2006). Análisis intertextual del film "Vivir su vida". Madrid.

Bordwell, D. (1985). La narración en el cine de ficción. Barcelona: Ediciones Paidóslbérica, S.A.

Bordwell, D. (1996). La narración canónica. Barcelona: Editorial Paiadós.

Burch, N. (1979). Praxis del cine. Madrid: Editorial Fundamentos.

Burch, N. (4 de 12 de 1987). El tragaluz del infinito. Madrid: CÁTEDRA. Obtenido de http://www. hamalweb.com.ar/hamal/textos/burch-el-tragaluz-del-infinito-publi.pdf.pdf

Churion, R. (5 de Septiembre de 2005). Análisis comparativos entre los estilos de dirección cinematográfica de la Nouvelle Vague y Hollywood. Caracas: Universidad Católica Andrés Bello.

David Bordwell, K. T. (1997). El cine clásico de Hollywood: estilo cinematográfico y modo de producción hasta 1960. Barcelona: Paidós Comunicación Cine.

GIL, M. M. (25 de Agosto de 2001). Wollheim: "No entiendo cómo se aplica el minimalismo a la arquitectura o la moda». Obtenido de HEMEROTECA : http://www.abc.es/hemeroteca/ historico-25-08-2001/abc/Cultura/wollheim-no-entiendo-como-se-aplica-el-minimalismo-ala-arquitectura-o-la-moda_42270.html

Godard, J.-L. (Dirección). (1960). À bout de souffle [Película].

Godard, J.-L. (Dirección). (1962). Vivre sa vie [Película].

Godard, J.-L. (Dirección). (1963). Le mépris [Película].

Habermas, J. (1994). Teoría de la acción comunicativa. Madrid: Ediciones Cátedra.

Jacques Aumont, M. M., \& Marie, M. (1990). Análisis del film. Barcelona: PAIDOS IBERICA.

Joly, M. (2005). El enfoque semiológico. En M. Joly, La imagen fija (págs. 17-47). Buenos Aires: LA MARCA. 
Llosa, M. V. (2012). La civilización del espectáculo. Madrid: Editorial alfaguara.

Ministerio de Educación Nacional de Colombia . (2017). Propuesta de documento de discusión para la formulación de lineamientos sobre pertinencia en la educación superior colombiana. Bogotá.

Ministerio de Educación, C. y. (Dirección). (2002). Amar el cine [Película].

Mitry, J. (2002). Estética y psicoanálisis del cine. Madrid: Siglo XXI de España Editoriales, S.A.

Olaskoaga, A. (2015). El mercado del cine en EEUU octubre 2015. Los Ángeles: Estudios de Mercado.

Piaget, J. (2009). La psicología de la inteligencia. Barcelona: Biblioteca de Bolsillo.

Pineda, C. M. (19 de Enero de 2018). Canon fílmico hegemónico hollywoodense. (S. A. Berío, Entrevistador)

Roland, B. (1971). Elementos de semiología. En B. Roland, Elementos de semiologia (pág. 9). Madrid: Comunicación Serie B.

Sampieri, Fernandez, \& Batista. (2006). Metodología de investigación. Ciudad de México: MCGRAWHILL.

Sirk, D. (Dirección). (1955). All that Heaven Allows [Película].

Sorini, P. (1996). Cines europeos, sociedades europeas 1939-1990. Barcelona: Paidós Iberica .

Truffaut, F. (Dirección). (1961). Jules et Jim [Película].

Wilder, B. (Dirección). (1959). Some Like It Hot [Película].

Wilder, B. (Dirección). (1960). The Apartment [Película].

\section{Notas}

[1]Revista icónica de crítica cinematográfica.

[2]Término francés para referirse a alguien transgresor y revolucionario en el arte.

[3]Significante, corresponde a los elementos tangibles o materiales. (Joly, 2005)

[4]Se utiliza el término "racionaliza" en el sentido de "noúmeno", porque el espectador ya ha pasado por todo el proceso de semiosis que implica el elemento emocional de descifrar el signo y significante "noema", el principio de una Idea (Habermas, 1994).

[5]Significado, corresponde a los elementos no tangibles o que suscita a los conceptos; no a la materia. (Joly, 2005)

[6]Relación de causa y efecto del canon fímico hollywoodense, en la que un suceso no pasa por que sí, ocurre porque hay una cadena de eventos que la generan. (Bordwell, La narración canónica, 1996)

[7]Se refiere a "pinturas", en francés. Y es la forma en la que Godard divide Vivre sa vie.

[8]Bertolt Brech, dramaturgo alemán que formuló la teoría dialéctica en el teatrvo. Su arte se caracterizaba por una confrontación entre el actor y el espectador, en una atmósfera en la que le planteaba al público un escenario satírico, donde se burlaba de la ilusión de "realidad "contradictoria que quería formar el teatro del entretenimiento en el espectador. Su teatro se encausa en hacer partícipe al público de la obra. (Pineda, 2018)

[9]Término usado por Bordwell, retomado de Bruch (Burch, Praxis del cine, 1979) quien se refiere únicamente a parámetros.

[10]El término "ideas" se refiere a "noúmeno", como un proceso del espectador. 
[11]En la narrativa del clasicismo hollywoodense, la narrativa aristotélica, la estilística en dependencia por la narrativa. (Bordwell, La narración canónica, 1996)

[12]Convencionalismo de signos entre el espectador y la película. (Arias, 2017)

[13] El cine de Hollywood "se ha consolidado como hegemónico y es en consecuencia el que más ha calado en el imaginario colectivo global, estableciendo los cánones del lenguaje audiovisual, la estética visual y acaparando las carteleras alrededor del globo" (Olaskoaga, 2015, pág. 8).

[14]Movimiento cinematográfico que buscaba reivindicar el valor artístico del cine. (Bordwell, La narración en el cine de ficción, 1985)

[15]Movimiento cinematográfico generado en la Unión Soviética que ratificar la idea del cine como un discurso de una parte de la realidad que siempre iba tener una intención propagandística. (Aumont, Bergala, Michel, \& Vernet, 2008)

[16]El término es extraído de la corriente del pensamiento estructuralista, o lo que es lo mismo al análisis de las estructuras. Según Barthes, "se propone reconstruir el funcionamiento de los sistemas de significación" (Roland, 1971, pág. 9).

[17]Elemento hollywoodense de la construcción fotográfica de los planos que busca mantener la continuidad en el relato mientras los personajes expresan su diálogo, si es que entre los personajes hay una interacción comunicativa.

[18]Al preguntarle por el minimalismo al filósofo Richard Wollheim, él responde: utilicé el término "arte minimalista" para definir obras diferentes, pero con algo en común: habían trastocado poco la superficie pictórica, eran más bien cuadros monocromáticos. Había mucha complejidad en el cuadro, al reagrupar elementos encontrados no necesariamente en la naturaleza, sino como resultado de un proceso industrial. Son obras de segundo orden, con un papel semididáctico que nos hace pensar sobre lo que es el arte. Cuando vamos a un museo, deberíamos pensar que estamos en un entorno en el que tenemos enfrente obras de arte y punto, dejando atrás cuestiones filosóficas. (GIL, 2001)

[19] Una toma que registra en movimiento. La cámara permanece fija y se desplaza por un móvil sobre el que está ubicada, registrando aquello que está dentro de su campo (Mitry, 2002).

[20] La película del cine canónico de Hollywood es una búsqueda permanente por la realidad diegética o verosímil donde se plasme algún episodio de la vida humana de manera cinematográfica, representando la "realidad" lo más exacta que se pueda desde el contexto social de la época con la identidad social, normas morales y verdades absolutas por donde los personajes deben cruzar para cumplir sus objetivos y motivaciones (Bordwell, La narración canónica, 1996). A su vez, esta ha sido usado como discurso para alienación a través del entretenimiento, "modelo clásico (...) para desinformar y adormecer a las masas populares" (Burch, El tragaluz del infinito, 1987, pág. 16). Y también ha sido implantada como medio propagandístico para instituir un modelo hegemónico desde capitalismo, la moral, los estereotipos, arquetipos, prototipos, ideales y valores de la sociedad estadounidense en occidente (Pineda, 2018).

[21] Reconocido movimiento social por frases como "Prohibido prohibir", Mayo del 68, hizo parte de las marchas estudiantiles y reaccionarias a los gobiernos militares que se impusieron durante la época posterior a la Segunda Guerra Mundial. Fue un movimiento gestado en París que desencadenó una serie de protestas impulsadas por estudiantes de izquierda contra las sociedades dictatoriales y de consumo. (Llosa, 2012) Godard participó activamente, parte de esta militancia la desarrolló en La cause du peuple, gaceta maoísta que cuestionaba el orden político de la época.

\section{Para citar este artículo}

Segura, S. (2020). El discurso godardiano en Vivre Sa Vie (1962) . Revista Luciérnaga Comunicación. Vol.12 Núm. 23. Pp 150-164. https://doi.org/10.33571/revistaluciernaga.v12n23a7

\section{Ojs. https://revistas.elpoli.edu.co/index.php/luc/issue/archive}

Link. https://www.politecnicojic.edu.co/index.php/revista-luciernaga 